\title{
Morphological and Phenotypic Effects of Fast Neutron Irradiation (FNI) on Lagos Spinach (Celosia argentea L.)
}

\author{
Abubakar Abdulhakeem*, Falusi Ahmed Olamide, Daudu Oladipupo Abdulazeez Yusuf \\ Department of Biological Sciences, Federal University of Technology, Minna, Nigeria
}

Email address:

abuakim2007@gmail.com (A. Abdulhakeem)

${ }^{*}$ Corresponding author

\section{To cite this article:}

Abubakar Abdulhakeem, Falusi Ahmed Olamide, Daudu Oladipupo Abdulazeez Yusuf. Morphological and Phenotypic Effects of Fast Neutron Irradiation (FNI) on Lagos Spinach (Celosia argentea L.). Radiation Science and Technology. Vol. 3, No. 5, 2017 , pp. 47-53. doi: $10.11648 /$ j.rst.20170305.12

Received: August 15, 2017; Accepted: September 9, 2017; Published: October 10, 2017

\begin{abstract}
Fast neutrons irradiation is a valuable tool for developing varieties with high agricultural potentials and economic values. Therefore, the research was carried to evaluate effects of fast neutron irradiation on the morphology and phenotype of Lagos spinach, with the aim of inducing useful agronomical traits for selection of desirable genotypes that could be used for large scale production. The Celosia argentia (Red accession) that were used for the experiment were obtained from local farmers in Kwara State. A total of five groups containing 250 healthy dry seeds of $C$. argentea were selected and exposed to fast neutron irradiation from Americium-Beryllium sources $\left({ }^{241} \mathrm{Am} / \mathrm{Be}\right)$, of flux density $1.5 \times 10^{4} \mathrm{n} . \mathrm{cm}^{-2} \mathrm{~S}^{-1}$ for different time regimes (30, 60, 90 and 120 mins). A non-irradiated group was termed as control. The seeds were plated in the laboratory for germination study and in experimental pots arranged in randomized completely block design (RCBD) in the garden. Each treatment was replicated five times. Results of morphological estimate showed that with the exception of plant height at 2 week after thinning (WAT), significant $(\mathrm{P} \leq 0.05)$ highest ranged of plant height $(19.54-77.48 \mathrm{~cm})$, stem diameter $(7.00-9.64$ $\mathrm{cm})$, number of leaves $(46.40-77.40)$ and leaf area $\left(32.17-40.83 \mathrm{~cm}^{2}\right)$ were record in 60 minutes irradiated seed plants throughout the experimental period. The least values were obtained in the control plant. Adaptability of the mutant resulted in higher spike production parameters in $\mathrm{M}_{2}$ compared to $\mathrm{M}_{1}$. Phenotypic expression of the mutant leaves revealed different forms of aberrations ranging from invagination of leaf apex, dented edges, wrinkle shapes and leaf chlorosis. $C$. argentea being an edible leafy vegetable with significant improvement in the morphological leafy parameters for all the irradiated plants indicated that, FNI is a good tool for improvement in Lagos spinach with best irradiation dosage being 60 minutes of exposure.
\end{abstract}

Keywords: Celosia argentea, Fast Neutron, Leaf Aberration, Morphology, Phenotypic

\section{Introduction}

Leafy vegetables play a critical role in human life due to the importance as the only alternative sources of medicine, nutrition and cash income [1]. Celosia argentea, commonly known as Lagos Spinach, is an edible leafy vegetable of the Amaranthaceae family. It is known as "Soko Yòkòtò" in Yoruba and "Farar áláyyafó" Hausa [2]. This leafy vegetable is an essential component of people's diet in Nigeria and other parts of West Africa [3]. The leaves and young shoots of both forms are used in soups and stews. The leaves contain high levels of calcium, phosphorus and iron. The plant is an important source of proteins, calories, vitamins and minerals [4].
The different uses of Lagos spinash have led to increase in its demand among people and inevitably followed by increased production of the crop. However, inadequate improved varieties of this crop species as well as other cultural and environmental driven problems have limited its production. It has been evidently shown that, the varieties under cultivation are having limited yield potential [5]. However, few researches on improvement of Lagos spinach resulted in considerable increased in yield but could not meet the demand of its large population consumers. Consequently, efforts is been shifted towards improvement of the crops through mutation breeding techniques. 
Induction of mutation played a vital role in the crop improvement among modern methods of plant breeding through creation of genetic variability. Genetic variability and extent to which the traits are heritable are effective for enhancing quantitative and qualitative characters [6], also widening the genetic base of the crop involved. Effective induction of useful mutations could be achieved using fast neutron irradiation (FNI) doses [7], and the traits of the resulting mutants can be stably inherited [8]. In recent years, effective used of FNI for improvement in yield and morphological parameters of Nigerian crop species have reported for pepper $[9,10]$ and in Sesame [11, 12]. Therefore, study was undertaken to evaluate the morphological and phenotypic effects of fast neutron irradiation in Lagos spinach with the aim of inducing changes in the genotype to enhance its genetic variability as well as broaden its genetic base for selection of desirable genotypes that could be used for large scale production and improvement of the crop in the future.

\section{Materials and Methods}

\subsection{FNI Induction Procedure}

A total of 250 healthy dry seeds of the Celosia argentea were exposed to fast neutron irradiation from Americium Beryllium sources $\left({ }^{241} \mathrm{Am} / \mathrm{Be}\right)$, of flux density $1.5 \times 10^{4}$ n.cm $\mathrm{cm}^{-2}$ for $30,60,90$ and 120 minutes equivalents to 4,8 , 12 and $16 \mu$ Svat the Centre for Energy and Research Training (CERT), Ahmadu Bello University, Zaria, Kaduna State, Nigeria. The non irradiated seeds served as Controls.

\subsection{Seed Germination Test}

The treated seeds and control were planted both in both laboratory and on the field. In the laboratory, 100 seeds per treatment were planted on petri-dishes lined with pre-soaked filter paper to test for seed germination. After 7 days of sowing, number of seeds germinated were counted and expressed in percentage [13].

\subsection{Seed Planting and Management}

For field experiment, 5 randomly selected seeds of each treatment were planted in 7 litres pots; fill to 5 litres mark with sandy-loamy soil to obtain the seedlings. The plants were water once daily between 6.30-7.30 am using bore-hole water in the absence of rain. The seedlings were then tinned to 2 seedlings per pot after 3 weeks of planting and sprayed with an insecticide after three (3) weeks of the thinning to prevent insect attack and diseases. No fertilizer was applied. Each treatment were replicated five times using randomized completely block design (RCBD) [14, 15].

The morphological parameters such as plant height $(\mathrm{cm})$, number of leaves/plant, stem diameter $(\mathrm{cm})$, leaf length and width $\left(\mathrm{cm}^{2}\right)$ were measured at 2 weeks interval for 2 months and number of spike/plant and length of middle spike/plant (cm) at maturity stage. The seed of the $\mathrm{M}_{1}$ were re-planted to obtained $\mathrm{M}_{2}$ generation and spike production parameters were taken and compared to $\mathrm{M}_{1}$.

\subsection{Data Collection and Analysis}

Data collected were subjected to analysis of variance (ANOVA) using SPSS version 20 tocompare the meansand Duncan Multiple Range Tests (DMRT) were used to separate the means. Student t-test was used to compare spike production parameters of $\mathrm{M}_{1}$ and $\mathrm{M}_{2}$. Other data obtained were expressed in percentage.

\section{Results}

\subsection{Effects of FNI on Germination and Survival Percentage $C$. argentea}

The results of effects of FNI on germination of seed and survival of plant to maturity were presented in figure 1 . Slight reductions in germination percentage with increased irradiation time of exposure were observed from 90 (86.6\%) to $120(80.00 \%)$ minutes exposure times. Highest percentage survival among all the irradiated treatment plants were due 30 and 90 minutes exposure time with a value of $86.67 \%$ while the least of $80 \%$ was recorded in 120 minutes irradiated treatment. However, these values were less than the control value $(96.00 \%)$.

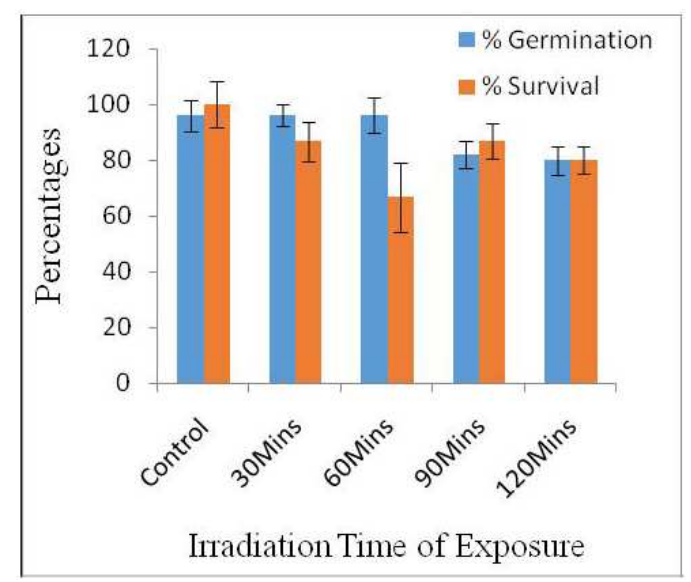

Figure 1. Germination and Survival Percentage C. argentea Varieties Treated with FNI.

\subsection{Effects of FNI on Morphological Parameters of Celosia argentea}

The results in table 1 showed the effects of Fast Neutron Irradiation (FNI) on morphological parameters of $C$. argentea. Statistical analysis of variance (ANOVA) showed that, there was no significant difference $(p \geq 0.05)$ among height of plants exposed to different irradiation time and the control plants at 2 weeks after thinning (WAT). With the exception of 60 minutes irradiated exposed plants, all other irradiated plants had reduced plant height at 2 WAT. As the week progresses, significant variation $(\mathrm{p} \leq 0.05)$ in plant height were observed with the highest mean of plant height consistently obtained in 60 minutes irradiated plants throughout the experimental period. The values obtained are 
$19.54 \mathrm{~cm}, 39.36 \mathrm{~cm}, 63.53 \mathrm{~cm}$ and $77.48 \mathrm{~cm}$ for week $2,4,6$ and 8 WAT respectively. These values were significantly $(p \leq 0.05)$ higher than the height of control and all other irradiated exposed plants. An exception to this general trend was noticed for the week 2 after thinning they were statistically the same (Table 1). Lowest mean plant height was also consistently due the control throughout the study period with the values of $18.56 \mathrm{~cm}, 18.64 \mathrm{~cm}, 28.06 \mathrm{~cm}$ and $55.18 \mathrm{~cm}$ at week 2, 4, 6 and 8 WAT respectively.

Significant variation $(\mathrm{p} \leq 0.05)$ among the stem diameters for all the irradiated and control plants were recorded in 2 and 4 WAT. The least stem diameter throughout the study period was due control plants with values of $4.82 \mathrm{~cm}, 5.74 \mathrm{~cm}$, $6.28 \mathrm{~cm}$ and $8.02 \mathrm{~cm}$ for $2,4,6$ and 8 WAT respectively. Significant highest stem diameter were obtained in 60 minutes irradiated plants; $7.00 \mathrm{~cm}, 8.78 \mathrm{~cm}, 9.04 \mathrm{~cm}$ and $9.64 \mathrm{~cm}$ for 2, 4, 6 and 8 WAT respectively. At 6 and 8 WAT, though the highest value for stem diameter $(9.04 \mathrm{~cm}$ and $9.64 \mathrm{~cm}$ respectively) was due to 60 minutes irradiated plants, this value was not significantly different $(p \geq 0.05)$ from that of the controls $(6.28 \mathrm{~cm}$ and $8.02 \mathrm{~cm}$ for week 6 and 8 respectively) and those of other treatments (Table 1).

Quantitative estimation of number of leaves at 2 weeks after thinning showed that the highest mean number of leaves was recorded in 60 minutes irradiated plants and the least was due to the control throughout the study period. Statistical analysis showed that there were significant differences $(p \leq 0.05)$ in mean number of leaves among all the plants irradiated for all the weeks. Significant highest mean numbers of leaves were due to 60 minutes FNI in all the weeks with the values of $46.40,62.20,74.40$ and 77.00 leaves for 2, 4, 6 and 8 WAT. These values were significantly higher than the values of control plants (Table 1).

Estimation of leaf areas for all the irradiated plants when compared with the control were significantly $(\mathrm{p} \leq 0.05)$ higher for all the weeks of study. At the end of 8 WAT, the leaf areas of all the treated plants were higher than the control $\left(25.96 \mathrm{~cm}^{2}\right)$ plants. Significant highest mean leaf area $\left(40.83 \mathrm{~cm}^{2}\right)$ was recorded in 60 minutes irradiated plants, followed by 120 minutes with mean value of $36.76 \mathrm{~cm}^{2}$ (Table 1).

Table 1. Effects of FNI on Morphological Parameters of Celosia argentea.

\begin{tabular}{|c|c|c|c|c|c|}
\hline Parameters & Dose & 2 WAT & 4 WAT & 6 WAT & 8 WAT \\
\hline \multirow{4}{*}{ Plant Height(cm) } & Control & $18.56 \pm 2.40^{\mathrm{a}}$ & $18.64 \pm 2.32^{\mathrm{a}}$ & $28.06 \pm 4.29^{\mathrm{a}}$ & $55.18 \pm 3.45^{\mathrm{a}}$ \\
\hline & $30 \mathrm{~min}$ & $17.70 \pm 1.75^{\mathrm{a}}$ & $32.42 \pm 4.43^{\mathrm{b}}$ & $54.96 \pm 4.91^{\mathrm{b}}$ & $73.74 \pm 1.93^{b}$ \\
\hline & $60 \mathrm{~min}$ & $19.54 \pm 3.95^{\mathrm{a}}$ & $39.36 \pm 7.16^{\mathrm{c}}$ & $63.50 \pm 7.27^{\mathrm{c}}$ & $77.48 \pm 5.49^{c}$ \\
\hline & $120 \mathrm{~min}$ & $16.30 \pm 1.14^{\mathrm{a}}$ & $33.70 \pm 2.93^{b}$ & $56.10 \pm 3.78^{\mathrm{bc}}$ & $70.08 \pm 4.66^{b}$ \\
\hline \multirow{4}{*}{ Stem Diameter(cm) } & Control & $4.82 \pm 0.96^{\mathrm{a}}$ & $5.74 \pm 1.00^{\mathrm{a}}$ & $6.28 \pm 0.94^{\mathrm{a}}$ & $8.02 \pm 0.63^{\mathrm{a}}$ \\
\hline & $30 \mathrm{~min}$ & $6.56 \pm 0.27^{\mathrm{ab}}$ & $7.52 \pm 0.29^{b}$ & $8.80 \pm 0.46^{\mathrm{a}}$ & $9.02 \pm 0.52^{\mathrm{a}}$ \\
\hline & $90 \mathrm{~min}$ & $6.48 \pm 0.69^{\mathrm{ab}}$ & $7.18 \pm 0.69^{b}$ & $8.24 \pm 0.77^{\mathrm{a}}$ & $9.02 \pm 0.52^{\mathrm{a}}$ \\
\hline & $120 \mathrm{~min}$ & $6.94 \pm 0.43^{\mathrm{ab}}$ & $8.14 \pm 0.37^{\mathrm{c}}$ & $8.22 \pm 0.78^{\mathrm{a}}$ & $8.72 \pm 0.39^{\mathrm{a}}$ \\
\hline \multirow{5}{*}{ Number of Leaves } & Control & $25.80 \pm 3.41^{\mathrm{a}}$ & $33.60 \pm 4.22^{\mathrm{a}}$ & $39.40 \pm 4.19^{\mathrm{a}}$ & $51.00 \pm 5.59^{\mathrm{a}}$ \\
\hline & $30 \mathrm{~min}$ & $35.20 \pm 4.75^{b}$ & $57.80 \pm 6.75^{\mathrm{c}}$ & $59.20 \pm 5.33^{\mathrm{b}}$ & $76.80 \pm 6.32^{\mathrm{c}}$ \\
\hline & $60 \mathrm{~min}$ & $46.40 \pm 5.22^{\mathrm{c}}$ & $65.20 \pm 8.87^{\mathrm{d}}$ & $74.40 \pm 6.10^{\mathrm{c}}$ & $77.40 \pm 3.10^{\mathrm{c}}$ \\
\hline & $90 \mathrm{~min}$ & $34.60 \pm 5.52^{\mathrm{b}}$ & $48.60 \pm 5.41^{\mathrm{b}}$ & $57.80 \pm 4.75^{\mathrm{b}}$ & $57.80 \pm 4.75^{\mathrm{ab}}$ \\
\hline & $120 \mathrm{~min}$ & $43.80 \pm 2.63^{b c}$ & $62.20 \pm 6.70^{\mathrm{cd}}$ & $62.20 \pm 4.68^{b}$ & $62.20 \pm 4.68^{\mathrm{b}}$ \\
\hline \multirow{4}{*}{ leaves Area $\left(\mathrm{cm}^{2}\right)$} & Control & $19.47 \pm 2.04^{\mathrm{a}}$ & $22.01 \pm 4.78^{\mathrm{a}}$ & $25.02 \pm 2.77^{\mathrm{a}}$ & $25.96 \pm 3.80^{\mathrm{a}}$ \\
\hline & $60 \mathrm{~min}$ & $32.17 \pm 2.42^{b}$ & $36.39 \pm 3.19^{c}$ & $36.64 \pm 2.39^{c}$ & $40.83 \pm 2.96^{\mathrm{c}}$ \\
\hline & $90 \mathrm{~min}$ & $27.31 \pm 2.27^{\mathrm{ab}}$ & $28.50 \pm 2.92^{\mathrm{b}}$ & $31.34 \pm 4.42^{\mathrm{b}}$ & $32.89 \pm 4.08^{b}$ \\
\hline & $120 \mathrm{~min}$ & $28.87 \pm 3.84^{\mathrm{b}}$ & $29.16 \pm 3.83^{b}$ & $35.69 \pm 4.67^{\mathrm{c}}$ & $36.76 \pm 5.69^{\mathrm{bc}}$ \\
\hline
\end{tabular}

Values are means $\pm \mathrm{S}$. E, values followed by the same letter(s) along the column are not significantly different at $\mathrm{p}>0.05$ as tested by DMRT

\subsection{Comparative Effects of FNI on Spike Parameters of $M_{1}$ and $M_{2}$ Generations}

Analytical studied of plant at all the spike parameters produced by $M_{1}$ generation plants showed that they were no significant difference $(\mathrm{p} \geq 0.05)$ among all the treated plants and the controls. However, significant $(\mathrm{p} \leq 0.05)$ variations were recorded for the parameters among the treated plants and when compared to the control in $\mathrm{M}_{2}$ generation. The highest mean plant height at maturity for $\mathrm{M}_{1}$ and $\mathrm{M}_{2}$ generation $103.48 \mathrm{~cm}$ and $136.60 \mathrm{~cm}$ were obtained on 60 and 90 minutes irradiated plants respectively, while the least $92.72 \mathrm{~cm}$ and $106.96 \mathrm{~cm}$ for both generations were due to the control plants. With the exception of controls and 60 minutes irradiated plants, there were significant differences between the plants heights of both generations with higher plant height recorded in $\mathrm{M}_{2}$ generation (Table 2). Insignificant sequential and slightly reductions in the mean number of spikes and length of middle spike produced with increased time of irradiation exposure from 30 minutes (29.20 spikes and $18.26 \mathrm{~cm})$ to 120 minutes $(25.00$ spikes and $17.00 \mathrm{~cm})$ were obtained in $\mathrm{M}_{1}$ generation plants. These values were not significantly different from the values of the controls $(24.60$ spikes and $16.14 \mathrm{~cm}$ length). For $\mathrm{M}_{2}$ generation there were non-sequential variations with the highest mean number of spikes (71.40 spikes) and Length of middle spike $(20.46 \mathrm{~cm})$ recorded in 90 minutes irradiated plants while the least was due to 30 minutes irradiated plants; 46.75 spikes and 
$12.74 \mathrm{~cm}$ for length of middle spikes. These highest values (71.40 spikes and $20.46 \mathrm{~cm}$ length) were significantly different from that of control $(26.60$ spikes and $18.18 \mathrm{~cm}$ length) and other exposed (treated) plants (Table 2). Significant differences between the number of spikes for $M_{1}$ and $\mathrm{M}_{2}$ generation were recorded for all irradiated plants with more number of spikes obtained in $\mathrm{M}_{2}$, while the controls were statistically the same.

For length of middle spikes, significant higher length of middle spikes $(18.26 \mathrm{~cm}$ and $19.56 \mathrm{~cm}$ for 30 and 60 minutes irradiated plants) were obtained in $\mathrm{M}_{1}$ when compared to $\mathrm{M}_{2}$ $(12.74 \mathrm{~cm}$ and $16.24 \mathrm{~cm}$ for 30 and 60 minutes irradiated plants respectively). In contrary, significantly higher length of middle spikes $(20.46 \mathrm{~cm})$ was due to 90 minutes irradiated plants for $\mathrm{M}_{1}$ when compared to $\mathrm{M}_{2}$ with the value of $17.56 \mathrm{~cm}$ (Table 2).
Phenotypic evaluation of the leaves and spikes of the irradiated plants with respect to the control indicated that FNI impacted various degree of deformation on the leaves. These leaf deformations ranged from invagination of leaf apex, dented edges, wrinkle shapes and leaf chlorosis. These aberrations were present and prominent in the leaves of 120 minutes irradiated produced plants. Some of the leaves of 30 and 60 minutes irradiated plants had slightly dented, irregular margin and invaginated apex, while 90 minutes irradiation resulted in wrinkle shapes of some leaves (Figure 2B - D). Some leaves of plants irradiated for 120 minutes time of exposure had various deformation characters with some exhibited chlorophyll aberration (Chlorosis) (figure 2E). However, normal ovate-shaped leaf with acute apex of $C$. argentea was observed in the control (Figure 2A).

Table 2. Comparative Effects of FNI on Spike Parameters of $M_{1}$ and $M_{2}$ Generation of C. argentea at Harvest.

\begin{tabular}{|c|c|c|c|c|c|c|}
\hline \multirow{2}{*}{ Sample } & \multicolumn{2}{|c|}{ Plant Height at Maturity } & \multicolumn{2}{|c|}{ Number of Spike Per Plant } & \multicolumn{2}{|c|}{ Length of Middle Spike } \\
\hline & $\mathbf{M}_{1}(\mathbf{c m})$ & $\mathrm{M}_{2}(\mathrm{~cm})$ & $\mathbf{M}_{1}$ & $\mathbf{M}_{2}$ & $\mathbf{M}_{1}(\mathbf{c m})$ & $\mathbf{M}_{2}(\mathbf{c m})$ \\
\hline Control & $92.72 \pm 5.79^{\mathrm{a}}{ }_{\mathrm{a}}$ & $106.96 \pm 6.82^{\mathrm{a}}{ }_{\mathrm{a}}$ & $24.60 \pm 2.01^{\mathrm{a}}$ & $26.60 \pm 3.28^{\mathrm{a}}$ & $16.14 \pm 1.92^{\mathrm{a}}{ }_{\mathrm{a}}$ & $18.18 \pm 0.59^{\mathrm{b}}$ \\
\hline $30 \mathrm{~min}$ & $101.02 \pm 3.87^{\mathrm{a}}{ }_{\mathrm{a}}$ & $124.64 \pm 3.03^{\mathrm{ab}}{ }_{\mathrm{b}}$ & $29.20 \pm 3.57^{\mathrm{a}}{ }_{\mathrm{a}}$ & $46.75 \pm 7.03^{b}{ }_{b}$ & $18.26 \pm 1.13^{\mathrm{a}} \mathrm{b}$ & $12.74 \pm 1.45^{\mathrm{a}}{ }_{\mathrm{a}}$ \\
\hline $60 \mathrm{~min}$ & $103.48 \pm 7.10^{\mathrm{a}}{ }_{\mathrm{a}}$ & $105.56 \pm 3.68^{\mathrm{a}}{ }_{\mathrm{a}}$ & $27.00 \pm 4.59^{\mathrm{a}}{ }_{\mathrm{a}}$ & $49.75 \pm 6.51_{b}^{b}$ & $19.56 \pm 0.88^{\mathrm{a}}{ }_{\mathrm{b}}$ & $16.24 \pm 2.51^{\mathrm{ab}}{ }_{\mathrm{a}}$ \\
\hline $90 \mathrm{~min}$ & $99.56 \pm 3.25^{\mathrm{a}}{ }_{\mathrm{a}}$ & $136.60 \pm 9.23^{b}$ & $25.40 \pm 3.08_{\mathrm{a}}^{\mathrm{a}}$ & $71.40 \pm 7.50_{b}^{c}$ & $17.56 \pm 1.69^{\mathrm{a}}{ }_{\mathrm{a}}$ & $20.46 \pm 1.02^{\mathrm{b}}{ }_{\mathrm{b}}$ \\
\hline $120 \mathrm{~min}$ & $98.10 \pm 3.73^{\mathrm{a}}{ }_{\mathrm{a}}$ & $112.58 \pm 8.29^{\mathrm{ab}}{ }_{\mathrm{b}}$ & $25.00 \pm 2.10^{\mathrm{a}}{ }_{\mathrm{a}}$ & $63.50 \pm 8.87_{b}^{c}$ & $17.00 \pm 0.53^{\mathrm{a}} \mathrm{a}$ & $18.58 \pm 1.75^{\mathrm{b}}{ }_{\mathrm{a}}$ \\
\hline
\end{tabular}

M1 = Treated parent seedling

M2 = First generation seedling

$*$ Values are means $\pm \mathrm{S}$. E, Values followed by the same letter(s) along the column are not significantly different at $\mathrm{p}>0.05$ as tested by DMRT

Values followed by the same letter along the row for certain parameter are not significantly different at $\mathrm{p}>0.05$ as tested by $\mathrm{t}$-test

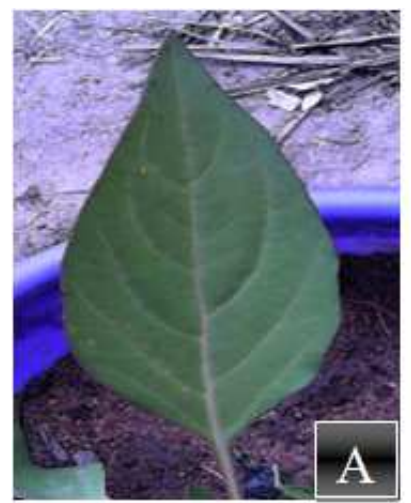

Control

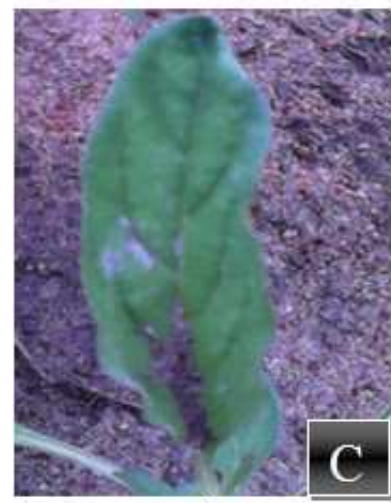

90 minutes

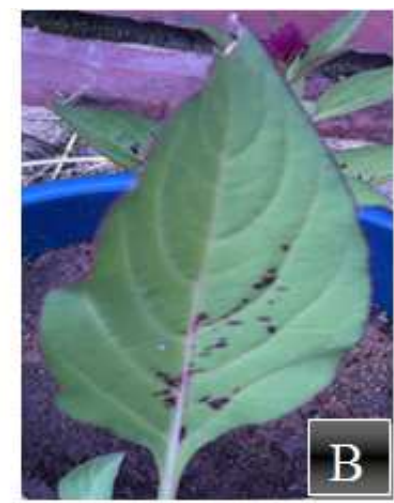

30 minutes

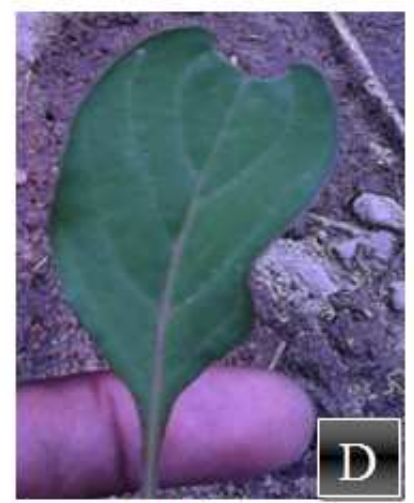

120 minutes

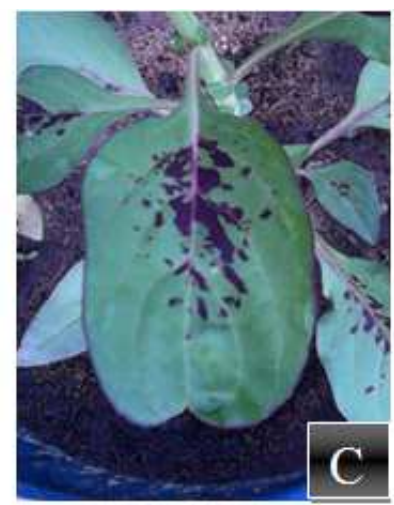

60 minutes

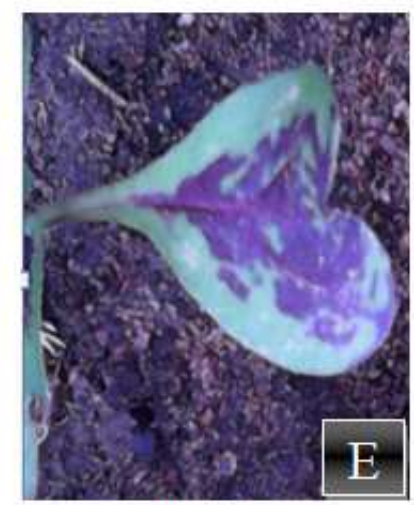

120 minutes

A: normal ovate leaf of C. argentea, B: dented, C: irregular margin and invaginated apex D: wrinkle shapes E: Chlorina mutated leaf

Figure 2. Phenotypic Effects of Fast Neutron Irradiation on Celosia argentea Leaves. 


\section{Discussion}

\subsection{Germination and Survival Percentage}

Reduction in the percentage germination recorded in this study, particularly at higher irradiated time of exposure conformed to the work of Muhanmu and kethekar [16], Domingo et al. [17]. They reported decrease trend of germination percentage with increased in mutagenic concentrations/doses. The decrease in germination may be attributed to mutagenic disturbances at cellular level due to changes either at physiological level or at physical level including chromosomal damages or due to the combination of both effects. Furthermore, disturbance in the formation of enzymes involved in the germination process could be one of the physiological effects caused by mutagen leading to decrease in germination [16]. The reduction in germination percentage might be due to chromosomal damage and lethal effects of the mutagen on meristematic tissues of the seeds thereby causing the prominent reduction in germination as compared to controls. Kumar and Yadav [18] had earlier made similar assertion.

Inconsistent reduction in survival percentage recoded in this study, could be due to the fact that survival rate depend on multiple factors, including the type of cell. Also, in support of this result Koing et al. [19] reported a reduction in the survival rate of mutagenized studied plants. They stated that, increasing in frequency of chromosomal damage with increasing radiation dose may be responsible for less germinability and reduction in plant growth and survival.

\subsection{Plant Height}

Plant height is a fundamental trait in breeding of an improve crop. Significantly, high mean of plants height recorded in irradiated plants relatively to the controls in the study, could be due to stimulation in the production of endogenous growth hormones such auxins to enhance proliferation of the cells. Low doses of radiation has been reported to increase the enzymatic activation and awakening of the stored energy necessary for initial growth in seed cotyledons, which results in stimulating the rate of cell division and affects not only germination, but also vegetative growth and flowering [20]. Contrast to these findings of Domingo et al. [17] reported reduction in height of $\mathrm{M}_{2}$ Oryza sativa cv Bahia (japonica) mutagenised with FN. Also, Hasbullah et al. [21] suggested that irradiation may prohibit the auxin activities and change the morphogenetic responses in plant.

\subsection{Stem Diameters}

Insignificant increased in stem diameters recorded in irradiated plants when compared with the control in this study, agrees with the work of El-Mokadem and Mostafa [22]. They reported insignificant effects of different sodium azide concentration with respect to stem diameter in the $\mathrm{M}_{1}$ generation of Browallia speciosa. In contrary to these results,
Rajib and Jagatpati [23] recorded decreased in stem diameter of Dianthus caryophyllus L. treated with chemical mutagens.

\subsection{Leave Number}

The increase in number of leaves per plant with increase in irradiation doses recorded in this study observed might be attributed to excitation of endogenous hormones involved in cell division and growth. This corroborates with the report that the number of leaves produced per plant and their proportionate distance from one another in mutagenised Jute (Corchorus olitorious L.) increases under different concentrations [24].

\subsection{Leaf Area}

Increased in leaf area obtained in this study was in consistent with the finding of Maluszynski et al. [25]. They reported an increased in leaf area among Zea mays mutants obtained due to irradiation with different concentration of mutagens. In support of the affirmation Nura et al. [24] reported that mutagens stimulated growth of the cells of the treated plants lamina thus, causing its remarkable expansion in area and provide large surface area for gaseous ex-change. Also, in agreement with the report Ainsworth et al. [26], suggested that mutation increases the genetic capacity for the utilization of photosynthates, due to the ability of plants to sustain increased photosynthesis.

\subsection{Comparative Effects of FNI on $M_{1}$ and $M_{2}$ Generation Plants at Harvest}

Non-significant variations recorded for all the number of spike and length of spike among the treated plants and the controls in $\mathrm{M}_{1}$ generation plants was in agreement with the work of El-Degwy and Hathout [27]. This might be due to partly Ittah et al. genetic stability and adaption mechanism of the plants to the induced variability. Significant variation in plant height and spike parameters recorded between $M_{1}$ and $\mathrm{M}_{2}$ for all of mutant populations and their progenies, and non-significant for both generation in the control populations with increased yield in $\mathrm{M}_{2}$, was similar to that obtained by [28] on yield traits, in $\mathrm{x}$ - ray irradiated groundnut mutants. They also reported that the direction of the phenotypic variations between $\mathrm{M}_{1}$ and $\mathrm{M}_{2}$ towards increase in characters of the $\mathrm{M}_{2}$ generations is indicator that, radiation was beneficial to the plants. The result of this study indicated that the magnitude of increase in variability differed for different traits and inconsistent with varying doses of the mutagen, this is in conformity with the work of Jagadeesan et al. [29].

\subsection{Phenotypic Effects on Leaves}

Various degree of aberration recorded in the leaves of the irradiated plants, with the deformation most prominent in 120 minutes exposed irradiated plant could be due to irreparable or mis-repaired DNA damage in cells directly hit by radiation or the damage nucleus cells of the seeds with resultant mutated expression. These results corroborate with the 
statement of Kadhim et al. [30]. They reported that deleterious effects of ionizing radiation, such as mutation and carcinogenesis, are attributed to damage to a cellular target, usually identified as nuclear DNA via direct absorption of radiation energy, the consequences of which are expressed in the surviving irradiated cells. Leaf aberration such as invaginated apex, irregular margin, wrinkle shapes and chlorine observed in the irradiated plants is in conformity with work of Falusi et al. [10] who studied the effects of fast neutron irradiationon Nigerian pepper. They reported various leaf irregularities such as small leaves area, chlorophylldeficient leaves, invaginated and inverted margins leaves, blunt and bifurcated apices leaves. Also, It has been reported that fast neutron irradiation, as a form of ionizing radiation with a high linear energy density, has the capability of causing secondary ionization and gene mutations in plant cells, and these traits of the resulting mutants can be stably inherited [8].

\section{Conclusion}

It can therefore be concluded that Fast Neutron Irradiation is a potent physical mutagen capable of inducing beneficial mutation in Lagos Spinach, Celosia argentea (red genotype). The magnitude of increase in variability differed for different traits, and inconsistent with different doses of the mutagen. The best irradiation period to induce this beneficial mutation is the 60 minutes irradiation exposure time. Generally speaking, the $\mathrm{M}_{2}$ plant performed better than the $\mathrm{M}_{1}$ plants in most of the parameters studied. It is therefore recommended that further experiment to test for the Geno-toxicity of the crop should be carried out; also those exposure periods that produced promising traits should be exploited further for future breeding programme of Lagos Spinach in the study area.

\section{References}

[1] Masarirambi MT, Sibandze N, Wahome PK, Oseni TO. Effects of kraal manure application rates on growth and yield of wild okra (Corchorus olitorius L.) in a sub-tropical environment. Asian Journal of Agricultural Science 2012; 4(1): 89-95.

[2] Remison SU. Basic principles of crop physiology. Benin City, Nigeria, Sadoh Press. 1997; Pp. 163.

[3] Kolawole EL, Peter AE. Growth and herbage yield of Celosia argentea as influenced by plant density and NPK fertilization in degraded ultisol. Tropical and Subtropical Agroecosystems 2011; 14(1): 251-260.

[4] Akinyemi SOS, Tijani-Eniola H. Effects of cassava density on productivity of productivity of plantain and cassava intercropping system. Fruits 1997; 50, 17-23.

[5] Grubben GJH. Botany. Vegetables, Google Books Result 2004: Available at www.books.google.com.ng/books?isbn=9057821478. Retrieve $\mathrm{d}$ on $12^{\text {th }}$ January, 2014.
[6] Bolbhat SN, Bhoge VD, Dhumal KN. Effect of Mutagens on Seed Germination, Plant Survival and Quantitative Characters of Horsegram (Macrotyloma uniflorum (Lam.) Verdc). International Journal of Life Science Botany and Pharma Research 2012; 2(4): 129 - 136.

[7] Zhang W, Endo S, Ishikawa M, Ikeda H, Hoshi M. Relative biological effectiveness of fission neutrons for producing micronuclei in the root-tip cells of onion seedlings after irradiation as dry seeds. Journal of Radiation Research (Tokyo) 2002; 43(4): 397-403.

[8] Wang JS, Sui JM, Xie YD, Guo HJ, Qiao LX, Zhao LL, Yu SL, Liu LX. Generation of peanut mutants by fast neutron irradiation combined with in vitro culture. Journal of Radiation Research 2015; 56(3): 437-445.

[9] Daudu OA, Falusi OA. Induced Genetic variability for morphological and Yield parameters in Capsicum annum and Capsicum frutescns. West Management and Bioresource Technology 2011; (1): 31-37.

[10] Falusi OA, Daudu OA, Teixeira da SJA. Effects of fast neutron irradiation on agronomic traits of Nigerian cpepper (Capsicum annuum L.). European Journal Horticultural Science 2012; 77(1): 41-45.

[11] Falusi OA, Abejide DR, Muhammad LM, Jaime ATS. Effect of Fast Neutron Irradiation (FNI) on pollen germinability of three Nigerian sesame varieties. International Journal of Biotechnology Research 2013; 1(6): 87-90.

[12] Muhammad LM, Falusi OA, Daudu OAY, Gado AA, Lateef AA, Yahaya SA. Radiation induced polygenic mutation in two common Nigerian sesame (Sesamum indicum L.) cultivars. International Journal of Biotechnology and Food Science 2013; 1(2): 23-28.

[13] Songsri P, Suriharn B, Sanitchon J, Srisawangwong S, Kesmala T. Effects of gamma radiation on germination and growth characteristics of Physic Nut (Jatropha curcas L.). Journal of Biological Sciences 2011; 11: 268-274

[14] Adamu AK, Aliyu H. Morphogical effects of sodium azide on Tomato (Lycopersicon esculentum Mill). Science World Journal 2007; 2(4): 9-12.

[15] Premjyoti CP. Studies on Induced Mutagenesis in Niger (Guizotia abysssinica Cass.). M. Sc. thesis submitted to the University of Agricultural Science, Dharwad 2006.

[16] Mahamune SE, Kothekar VS. Induced mutagenic frequency and spectrum of chlorophyl mutants in French bean. International Multidisciplinary Research 2012; 2(3): 30-32.

[17] Domingo C, Andrés F, Talón M. Rice cv. Bahia mutagenized population: a new resourcefor rice breeding in the Mediterranean basin. Spanish Journal of Agricultural Research 2007; 5(3): 341-347.

[18] Kumar G, Yadav RS. EMS induced genomic disorders in sesame (Sesamum indicum L.). Romanian Journal of Biology Plant Biology, Bucharest 2010; 55(2): 97-104.

[19] Kiong ALP, Lai AG, Hussein S, Harun AR. Physiological Responses of Orthosiphon Stamineus Plantles to Gamma Irradiation. American-Eurasian Journal of Sustainable Agriculture 2008; 2(2): 135-149.

[20] Moussa, HR. Role of gamma irradiation in regulation of $\mathrm{NO}_{3}$ level in rocket (Eruca vesicaria subsp. sativa) plants. Russian Journal of Plant Physiology 2006; 53(2): 193-197. 
[21] Hasbullah NA, Taha RM, Saleh A, Mahmad N. Irradiation effect on in vitro organogenesis, callus growth and plantlet development of Gerbera jamesonii. Horticultura Brasileira 2012; 30: 252-257.

[22] El-Mokadem H, Mostafa E, Gehan G. Induction of mutations in Browallia speciosa using sodium azide and identification of the genetic variation by peroxidase isozyme. African Journal of Biotechnology 2014; 13(1), 106-111.

[23] Rajib R, Jagatpati T. Chemical mutagenic action on seed germination and related agro-metrical traits in $\mathrm{M}_{1}$ Dianthus generation. Current Botany 2011; 2(8): 19-23.

[24] Nura S, Adamu AK, Mu'Azu S, Dangora DB. Chemical mutagenesis for improved quality traits in Jute (Corchorus olitorious L.). Continental Journal Biological Sciences 2011; 4(2): 22-27.

[25] Maluszynski M, Szarejko I, Barriga P, Balcerzyk A. Heterosis in crop mutant crosses and production of high yielding lines, using doubled haploid systems. Euphytica 2001; 120: 387398.
[26] Ainsworth EA, Rogers A, Nelson R, Long SP. Testing the source-sink hypothesis of down-regulation of photosynthesis in elevated $(\mathrm{CO} 2)$ in the field with gene substitutions in Glycine max. Agricultural and Forest Meteorology 2004; 122: 85-94.

[27] El-Degwy IS, Hathout MS. Influence of gamma rays on the performance and genetic parameters for grain yield and yield attributes of bread wheat. Egyptian Journal Agronomy 2014; 36(1): 41-55.

[28] Ittah MA, Binang WB, Shiyam JO, Idu PO. Genetic and correlation analyses of the variation in yield traits in $\mathrm{x}$ - ray irradiated groundnut mutants. Scirea Journal of Agriculture 2016; 1(1): 66-78.

[29] Jagadeesan S, Kandasamy G, Manivannan N, Muralidharan V. Mean and Variability Studies in $\mathrm{M}_{1}$ and $\mathrm{M}_{2}$ Generations of Sunflower (Helianthus annuus L.). Helia 2008; 31(49): 71-78.

[30] Kadhim M, Salomaa S, Wright E, Hildebrandt G, Belyakov OV, Prise KM, Little MP. Non-targeted effects of ionizing radiation-implications for lowdose risk. Mutation Research 2013; 752(1): 84-98. 